\title{
DEVELOPMENT OF A HIGH-POWER LITHIUM-ION BATTERY
}

\author{
by
}

A. N. Jansen, A. J. Kahaian, K. D. Kepler, P. A. Nelson, K. Amine,
D. W. Dees, D. R. Vissers, and M.M. Thackeray
Electrochemical Technology Program
Chemical Technology Division
Argonne National Laboratory
Argonne, IL U.S.A.

The submitted manuscript has been created by the University of Chicago as Operator of Argonne National Laboratory ("Argonne") under Contract No. W-31-109-ENG-38 with the U.S. Department of Energy. The U.S. Government retains for itself, and others acting on its behalf, a paid-up, nonexclusive, irrevocable worldwide license in said article to reproduce, prepare derivative works, distribute copies to the public, and perform publicly and display publicly, by or on behalf of the Government.

July 1998

To be presented at the 9th International Meeting on Lithium Batteries, Edinburgh, Scotland, United Kingdom, July 12-17, 1998 


\section{DISCLAIMER}

This report was prepared as an account of work sponsored by an agency of the United States Government. Neither the United States Government nor any agency thereof, nor any of their employees, make any warranty, express or implied, or assumes any legal liability or responsibility for the accuracy, completeness, or usefulness of any information, apparatus, product, or process disclosed, or represents that its use would not infringe privately owned rights. Reference herein to any specific commercial product, process, or service by trade name, trademark, manufacturer, or otherwise does not necessarily constitute or imply its endorsement, recommendation, or favoring by the United States Government or any agency thereof. The views and opinions of authors expressed herein do not necessarily state or reflect those of the United States Government or any agency thereof. 


\section{DISCLAIMER}

Portions of this document may be illegible in electronic image products. Images are produced from the best available original document. 


\title{
DEVELOPMENT OF A HIGH-POWER LITHIUM-ION BATTERY
}

\author{
A.N. Jansen*, A.J. Kahaian, K.D. Kepler, P.A. Nelson, K. Amine, D.W. Dees, \\ D.R. Vissers, and M.M. Thackeray \\ Argonne National Laboratory \\ Chemical Technology Division \\ Argonne, IL 60439, USA
}

Keywords: lithium titanium oxide, lithium ion, hybrid vehicle, safety

\begin{abstract}
:
Safety is a key concern for a high-power energy storage system such as will be required in a hybrid vehicle. Present lithium-ion technology, which uses a carbon/graphite negative electrode, lacks inherent safety for two main reasons: 1) carbon/graphite intercalates lithium at near lithium potential, and 2) there is no end-of-charge indicator in the voltage profile that can signal the onset of catastrophic oxygen evolution from the cathode $\left(\mathrm{LiCoO}_{2}\right)$. Our approach to solving these safety/life problems is to replace the graphite/carbon negative electrode with an electrode that exhibits stronger two-phase behavior further away from lithium potential, such as $\mathrm{Li}_{4} \mathrm{Ti}_{5} \mathrm{O}_{12}$. Cycle-life and pulse-power capability data are presented in accordance with the Partnership for a New Generation of Vehicles (PNGV) test procedures, as well as a full-scale design based on a spreadsheet model.
\end{abstract}

\section{Introduction}

In 1993, the Partnership for a New Generation of Vehicles (PNGV) Program was established between the United States government and the U.S. Council for Automotive Research (USCAR) and set a goal to develop the next generation of automobiles. The goal is the development of a production prototype for a six-passenger sedan automobile in the year 2004 that will achieve up to $80 \mathrm{mpg}$; have negligible environmental emissions and long driving range; and will be safe, fuel efficient, and capable of running on alternative fuels. It is unlikely that one power system alone will be capable of meeting such a high goal, and that situation has

* Corresponding author,e-mail: jansen @cmt.anl.gov; Tele: (630) 252-4261; FAX (630) 252-4176 
necessitated the development of a hybrid system. We believe that the best hybrid vehicle will incorporate a reformer and fuel cell coupled with a high-power energy-storage device.

The high-power energy storage device for a hybrid electric vehicle is the subject of this work. We are investigating the concept of integrating the galvanic properties of battery "insertion" electrodes and the geometric high surface areas of supercapacitors to engineer a high-power device referred to hereafter as a "galvanic stack". The galvanic stack should have high power capability $(1-5 \mathrm{~kW} / \mathrm{kg})$ and an energy density of at least 15-22 Wh/kg; it should be able to rapidly store and release large quantities of energy over hundreds of thousands of cycles.

Lithium-ion batteries have received much attention in the last several years as highenergy and high-power sources due to their high voltage and ambient temperature operation. These batteries are being used in portable electronic devices such as notebook computers, cellular phones, and power tools; they are also being considered for use in hybrid vehicles to supplement a main power source (e.g., internal combustion engine) and to recover energy during vehicle braking. As a power assist for hybrid vehicles, the battery must be able to rapidly store and release large quantities of energy and have a power-to-energy ratio approaching 100:1.

Such a high power demand necessitates a system that is inherently safe. Consideration has been given to the present "state-of-the-art" lithium-ion batteries, which consist of a negative electrode of lithiated carbon/graphite, a positive electrode of lithium cobalt oxide, and an electrolyte consisting of a lithium salt in an organic solvent. However, there are several concerns about the intrinsic safety of this type of battery during high power pulses. For example, carbon/graphite materials intercalate lithium at approximately $100 \mathrm{mV}$ (vs. lithium metal); under high power charge pulses, the carbon/graphite electrode can be polarized to the extent that highly reactive lithium metal is deposited on the surface of the electrode particles. If the thermal management system is inadequate (or fails), this lithium creates a hazardous and potentially catastrophic situation by reacting with the electrolyte and highly charged positive electrodes. Graphite/carbon-based electrodes also suffer from a lack of a clear end-of-charge indicator in their voltage profiles, as can be seen in Fig. 1. This can result in oxygen release and structural damage at the positive electrode. Severe overcharging, in particular, can lead to explosive events because of the presence of metallic lithium and free oxygen in the presence of an organic (flammable) electrolyte in a sealed container. 
Our approach to solving these safety/life problems is to replace the graphite/carbon negative electrode with an electrode that exhibits a strong two-phase behavior sufficiently far away from the potential of metallic lithium. Characteristic of a two-phase electrochemical reaction is a flat voltage response; in these reactions, a distinct change in voltage is evident as one phase becomes depleted, thus providing an end-of-charge indicator. These features are evident in the voltage profile for $\mathrm{Li}_{4} \mathrm{Ti}_{5} \mathrm{O}_{12}$ in $\mathrm{Fig}$. 1 . The spinel $\mathrm{Li}_{4} \mathrm{Ti}_{5} \mathrm{O}_{12}$ is an attractive candidate as the negative electrode because the reaction during charge, $\mathrm{Li}_{4} \mathrm{Ti}_{5} \mathrm{O}_{12} \rightleftharpoons \mathrm{Li}_{7} \mathrm{Ti}_{5} \mathrm{O}_{12}$, is two phase and occurs at approximately $1.55 \mathrm{~V}$ vs. lithium metal (theoretical capacity of $175 \mathrm{mAh} / \mathrm{g}$ ). When combined with 4-V positive electrode materials such as $\mathrm{LiCoO}_{2}, \mathrm{LiNiO}_{2}$, or $\mathrm{LiMn}_{2} \mathrm{O}_{4}$, a $2.5-\mathrm{V}$ cell can be constructed [1,2]. From a structural viewpoint, $\mathrm{Li}_{4} \mathrm{Ti}_{5} \mathrm{O}_{12}$ is an ideal insertion electrode; it exhibits negligible increase in the cubic unit cell parameters during charge and discharge, thereby providing a "zero-strain" system [2] (see Fig. 2). In this cell couple, the positive and negative electrodes are based on transition metal oxide electrodes, which have the capability of accommodating a significant amount of lithium within the host electrode structure. By restricting shallow limits of charge and discharge, the structural integrity of the electrodes is maintained, and this permits high cycle life to be obtained.

\section{Experimental}

The $\mathrm{Li}_{4} \mathrm{Ti}_{5} \mathrm{O}_{12}$ and $\mathrm{LiCoO}_{2}$ materials used in this work were made by solid-state reactions of lithium carbonate with titanium oxide (anatase) and cobalt carbonate, respectively, obtained from Aldrich Chemical Co. These oxides were blended with carbon and "Kynar Flex" binder (hexafluoropropylene-vinylidine fluoride copolymer from ELF Atochem) in tetrahydrofuran to make into electrode slurries. Each slurry was laminated onto flat glass sheet with a doctor blade, removed from the glass, vacuum oven dried, and punched into $1 / 4$-in.-diameter disks approximately $150-\mu \mathrm{m}$ thick. The electrodes were assembled into coin cells (size 1225) with Celgard 2400 as a separator and $1 \mathrm{M} \mathrm{LiPF}_{6}$ salt in a 50/50 blend of dimethyl carbonate/ethylene carbonate (FMC's Lectro-Tmsol-110). Cells were cycled in accordance with test profiles defined in the PNGV Battery Test Manual [3].

\section{Results and Discussion}

Initial efforts have been devoted to the $\mathrm{Li}_{4} \mathrm{Ti}_{5} \mathrm{O}_{12} / \mathrm{LiCoO}_{2}$ cell couple. Our cells have achieved over 117,000 life cycles to date, where a life cycle is the "100-Wh Life Cycle Test Profile" defined in reference [3]. Each cycle is $60-\mathrm{sec}$ long and consists of a 9-sec discharge 
pulse and a 10-sec charge pulse with a rest and slow charge in between. The life cycle requirement with this profile is 50,000 cycles for a Fast Response Engine and 120,000 cycles for a Slow Response Engine. The voltage data for one of these cells are presented in Fig. 3 for every $200^{\text {th }}$ cycle. These data and other electrochemical data indicate that hundreds of thousands of cycles can be obtained.

In keeping with the $4: 3$ ratio in voltage limits (mandated by the PNGV), this cell couple was operated between 2.7 and $2.0 \mathrm{~V}$ with an open-circuit voltage slightly below $2.4 \mathrm{~V}$ at $50 \%$ state-of-charge (SOC). This is evident from an inspection of Fig. 4, which is a plot of the open circuit voltage versus depth-of-discharge (DOD) that was obtained after 47,500 cycles of the PNGV 100-Wh Test Profile. This open-circuit voltage was obtained from the "Hybrid Pulse Power Characterization" (HPPC) test sequence defined in reference [3]. The area specific impedance (ASI) on charge and discharge was determined from the same HPPC data, and is presented in Fig. 5. The pulse-power capability was calculated from the ASI and open-circuit data for the 2.7 to $2.0 \mathrm{~V}$ window. These results are presented in Fig. 6 in the form of a "Sweet Spot" plot. This plot defines the useable DOD range as the region between the selected discharge pulse power and the selected regenerative (charge) pulse power [3].

A 400-V galvanic stack based on the $\mathrm{Li}_{4} \mathrm{Ti}_{5} \mathrm{O}_{12} / \mathrm{LiNi}_{0.82} \mathrm{CO}_{0.18} \mathrm{O}_{2}$ system was modeled using a Microsoft Excel spreadsheet program developed at ANL for predicting the performance of batteries and designing them for optimum performance. (Advantages are gained in cell cost if much of the cobalt in $\mathrm{LiCoO}_{2}$ is replaced with nickel. Such substitution has little effect on the voltage window and theoretical capacity.) Stack units were designed that consist of 144 spiral wound cells divided into 8 modules enclosed in a thermally controlled jacket. Design parameters for individual cells, modules, and the complete $400-\mathrm{V}$ galvanic stack are presented in Table 1. The cells are cooled by air blown through finned intercell connectors, thus providing cooling directly to the cell terminals. The electrodes are coated on both sides of an aluminum current collector that is $15-\mu \mathrm{m}$ thick. To simplify preliminary design of the galvanic stack, it was assumed that the electrodes and separator materials are wound to form a cylindrical cell. Large savings in volume (and weight) may be realized by considering flat-wound cell designs and also hexagonal packing within the module. From this analysis, we found that the PNGV energy requirement of $0.3 \mathrm{kWh}$ (Fast Response Engine) is easily met. However, the ASI for this cell was assumed to be $9 \Omega-\mathrm{cm}^{2}$, but the present $\mathrm{Li}_{4} \mathrm{Ti}_{5} \mathrm{O}_{12} / \mathrm{LiCoO}$ cells have an $\mathrm{ASI}$ approximately three times this value $\left(-30 \Omega-\mathrm{cm}^{2}\right.$ at $40 \%$ DOD). In reference to Fig. 6 , the model 
predicts that a pulse power capability of $61 \mathrm{~mW} / \mathrm{cm}^{2}$ would be required for the discharge pulse and $92 \mathrm{~mW} / \mathrm{cm}^{2}$ for the charge pulse.

The biggest obstacle to meeting the target goals for this galvanic stack design is reducing the ASI by a factor of three. Several approaches are being taken to accomplish this goal: optimizing the concentrations of binder, conductive additives, and porosity to improve particle-to-particle contact; coating a thin metal substrate to improve current distribution; reducing the particle size to enhance lithium-ion diffusion; and modifying the morphology of the oxide structures to enhance lithium-ion diffusion and improve electronic conductivity. Also, some concern exists about the validity of scaling-up to a full-size stack design based on data from coin-size cells. Hence, larger cell designs with flooded electrolyte are being made to address this concern.

While the results obtained from the $\mathrm{Li}_{4} \mathrm{Ti}_{5} \mathrm{O}_{12} / \mathrm{LiNi}_{1-y} \mathrm{Co}_{y} \mathrm{O}_{2}$ system are encouraging, some concern exists over the reduced energy density of the cell couple in comparison to the more common lithium-ion cells that use carbon or graphite as the negative electrode. Carbon/graphite has a theoretical capacity of $372 \mathrm{mAh} / \mathrm{g}$ and a potential of $\sim 100 \mathrm{mV}$ vs. Li. However, carbon and graphite can suffer from large irreversible capacity losses on the first charge, which is not the case for $\mathrm{Li}_{4} \mathrm{Ti}_{5} \mathrm{O}_{12}$. The reduced cell voltage of $\mathrm{Li}_{4} \mathrm{Ti}_{5} \mathrm{O}_{12}$ cells necessitates the use of at least $40 \%$ more cells in the $400-\mathrm{V}$ galvanic stack than conventional carbon-based cells. This results in additional hardware costs that may prove to be prohibitive for applications with low profit margins. Applications that will benefit greatly from this cell couple are those that require inherent safety as their number one priority, such as the hybrid vehicle. To overcome these shortcomings, efforts are being initiated to investigate alternative "lowvoltage" negative electrode materials to replace $\mathrm{Li}_{4} \mathrm{Ti}_{5} \mathrm{O}_{12}$.

Calorimetry tests will be conducted in the near future to confirm that the $\mathrm{Li}_{4} \mathrm{Ti}_{5} \mathrm{O}_{12} / \mathrm{LiCoO}_{2}$ cell couple is indeed inherently safe. These tests will aid in determining electrode materialelectrolyte interactions to gain insight into cell failure mechanisms and their relationship to safety. These data will be reported elsewhere.

\section{Conclusions}

The use of $\mathrm{Li}_{4} \mathrm{Ti}_{5} \mathrm{O}_{12}$ as a negative electrode in a high-power lithium-ion battery is feasible if the area specific impedance can be reduced to approximately $9 \Omega-\mathrm{cm}^{2}$, a reduction by a factor of three from the present value. Excellent cycle life was achieved for $\mathrm{Li}_{4} \mathrm{Ti}_{5} \mathrm{O}_{12} / \mathrm{LiCoO}_{2}$ cells, as is expected with lithium intercalation/de-intercalation into stable metal 
oxide structures. This cell couple may find its main use in high-power applications where safety is a primary concern, such as exists for hybrid electric vehicles.

\section{Acknowledgment}

This work was supported by the Department of Energy under the Partnership for a New Generation of Vehicles (PNGV) Program and by Argonne National Laboratory under LDRD number EEST 96-256R1. Thanks also to John T. Vaughey of Argonne National Laboratory for his crystallographic insight and to Yang Shao-Horn of Michigan Technological University for the preparation of $\mathrm{LiCoO}_{2}$.

\section{References}

1. E. Ferg, R. J. Gummow, A. de Kock, and M. M. Thackeray, J. Electrochem. Soc. 141, L147 (1994).

2. T. Ohzuku, A. Ueda, and N. Yamamoto, J. Electrochem. Soc. 142, 1431 (1995).

3. PNGV Battery Test Manual, Revision 1, Idaho National Engineering Laboratory (Department of Energy), DOE/ID-10597 (May, 1998). 
Table 1. Galvanic stack composed of 8 modules of 18 cells each in a $4 \times 2 \times 1$ module configuration. Cylindrical wound-cell design was assumed for simplicity.

\begin{tabular}{|l|c|l|c|}
\hline \multicolumn{2}{|c|}{ Cell Parameters } & \multicolumn{2}{c|}{ Stack Parameters } \\
\hline Diameter, $\mathrm{mm}$ & 36 & Number of Modules & 8 \\
\hline Height, $\mathrm{mm}$ & 89 & Jacket Thickness, $\mathrm{mm}$ & 8 \\
\hline Area Specific Imped., $\Omega-\mathrm{cm}^{2}$ & 9 & Pulse Discharge Power, $\mathrm{kW}$ & 40 \\
\hline Open-Circuit Volt. at 50\% DOD & 2.4 & Peak Regen. Power, kW & 60 \\
\hline Capacity, Ah & 6.34 & Available Energy, $\mathrm{kWh}$ & 0.6 \\
\hline Negative Electrode, $\mu \mathrm{m}$ & 70 & Total Energy, 1-h Rate, kWh & 2.1 \\
\hline Positive Electrode, $\mu \mathrm{m}$ & 52 & Weight, kg & 41 \\
\hline \multicolumn{1}{|c|}{ Module Parameters } & 18 & Volume, L & 35 \\
\hline Number of Cells & Specific Power, W/kg & 970 \\
\hline Dimensions, mm: $217 \mathrm{~L} \times 1$ 10W $x 123 \mathrm{H}$ & Specific Energy, Wh/kg & 15 \\
\hline
\end{tabular}




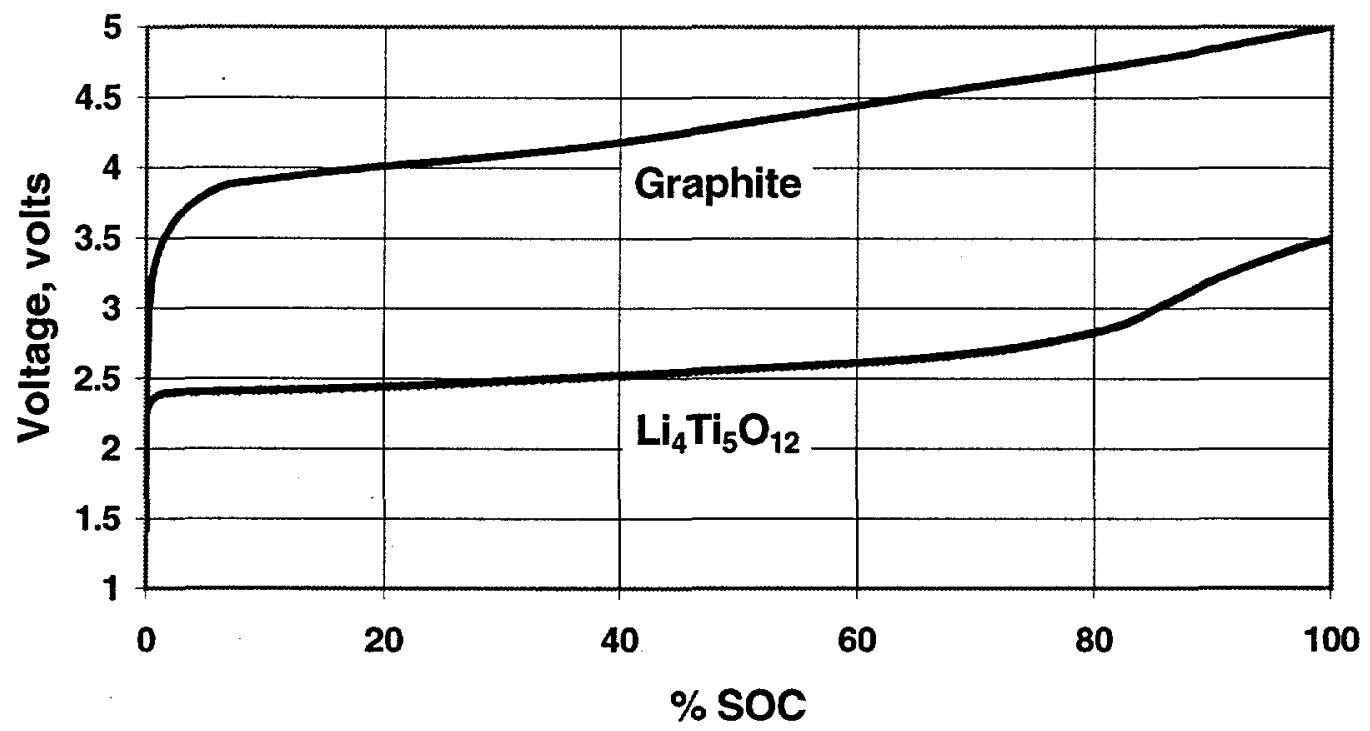

Fig. 1. Inherent safety provided by the rise in voltage at the end-of-charge for the $\mathrm{Li}_{4} \mathrm{Ti}_{5} \mathrm{O}_{12} / \mathrm{LiCoO}_{2}$ cell couple. No such end-of-charge indicator exists for the graphite/LiCOO 2 couple. 


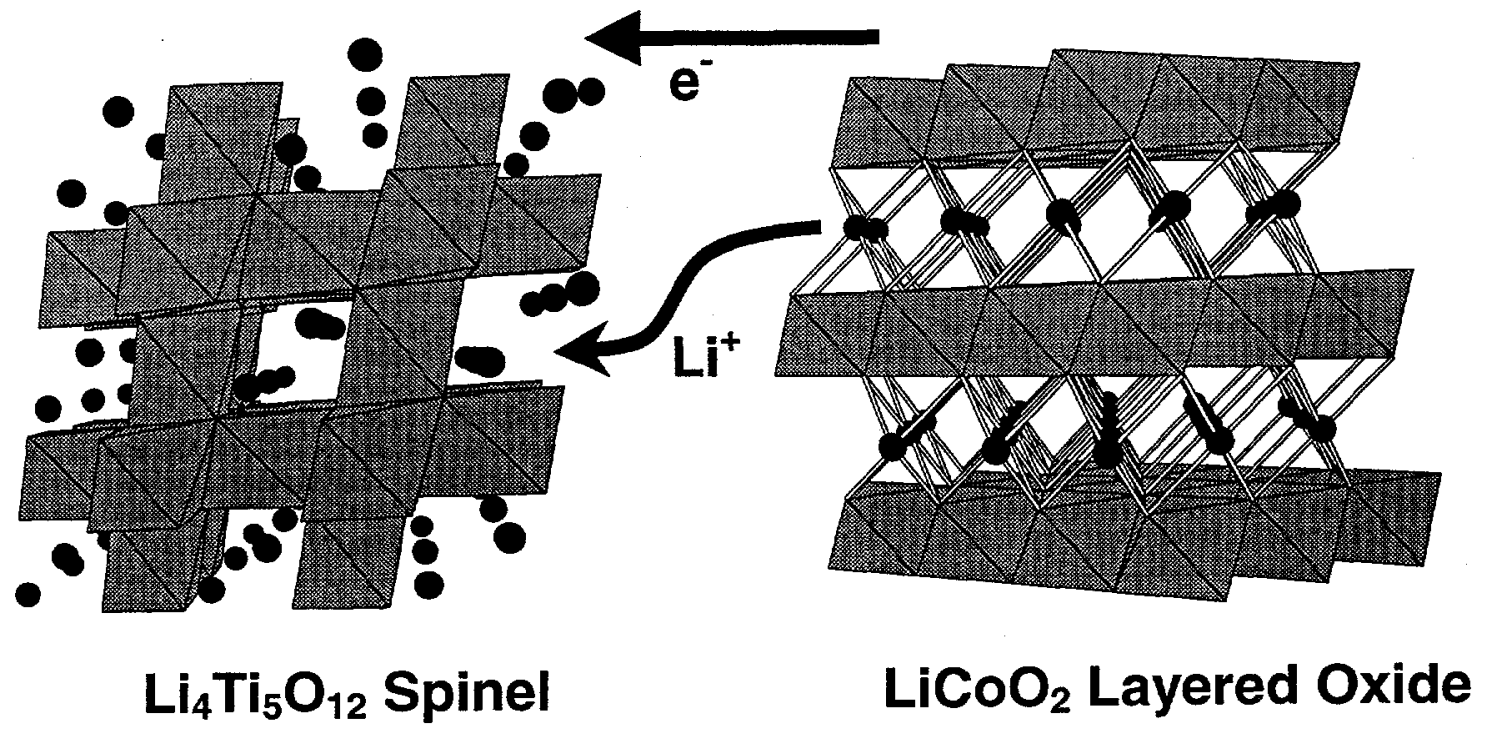

Fig. 2. Intercalation into the $\mathrm{Li}_{4} \mathrm{Ti}_{5} \mathrm{O}_{12}$ spinel and de-intercalation out of the $\mathrm{LiCoO}_{2}$ layered structure form an ideal cell couple. 


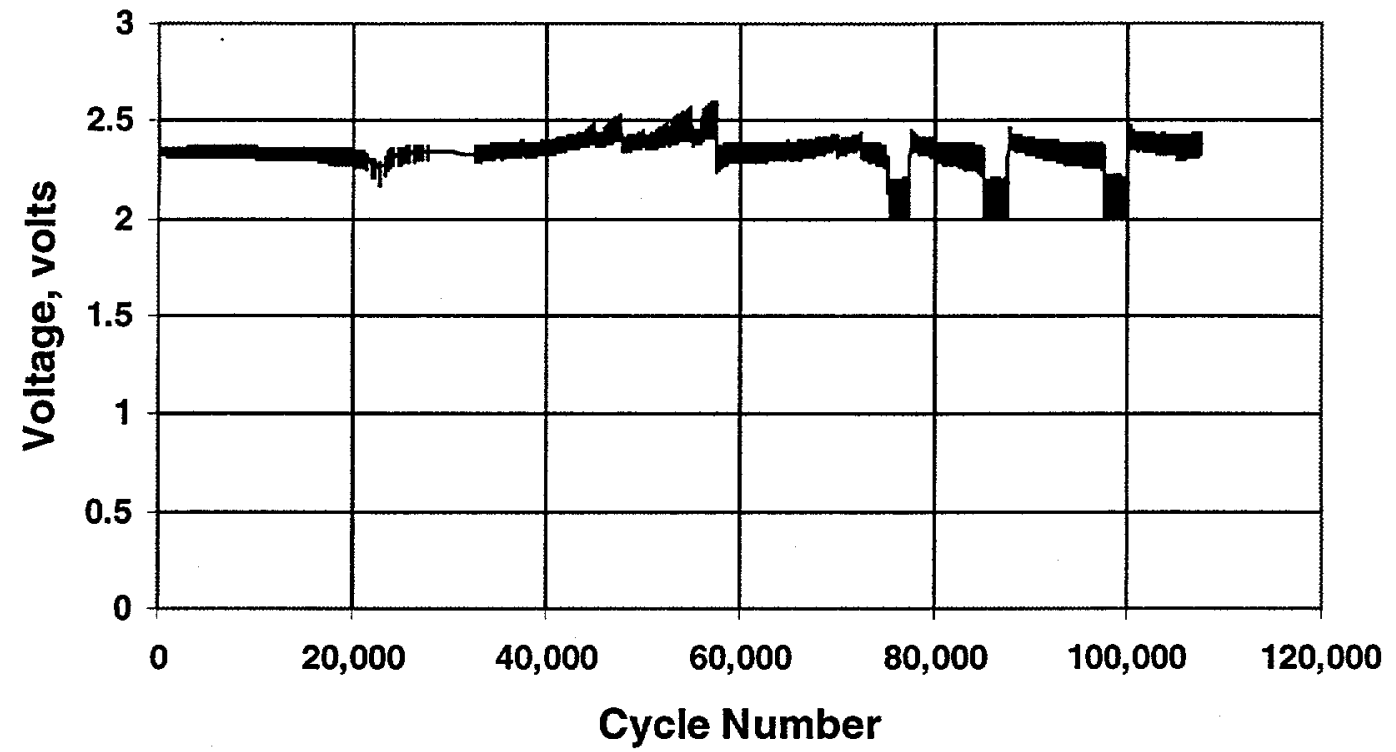

Fig. 3. Voltage profile for $\mathrm{a}_{4} \mathrm{Ti}_{5} \mathrm{O}_{12} / \mathrm{LiCoO}$ cell operated under the PNGV 100-Wh Test Profile. Data shown for every $200^{\text {th }}$ cycle. 


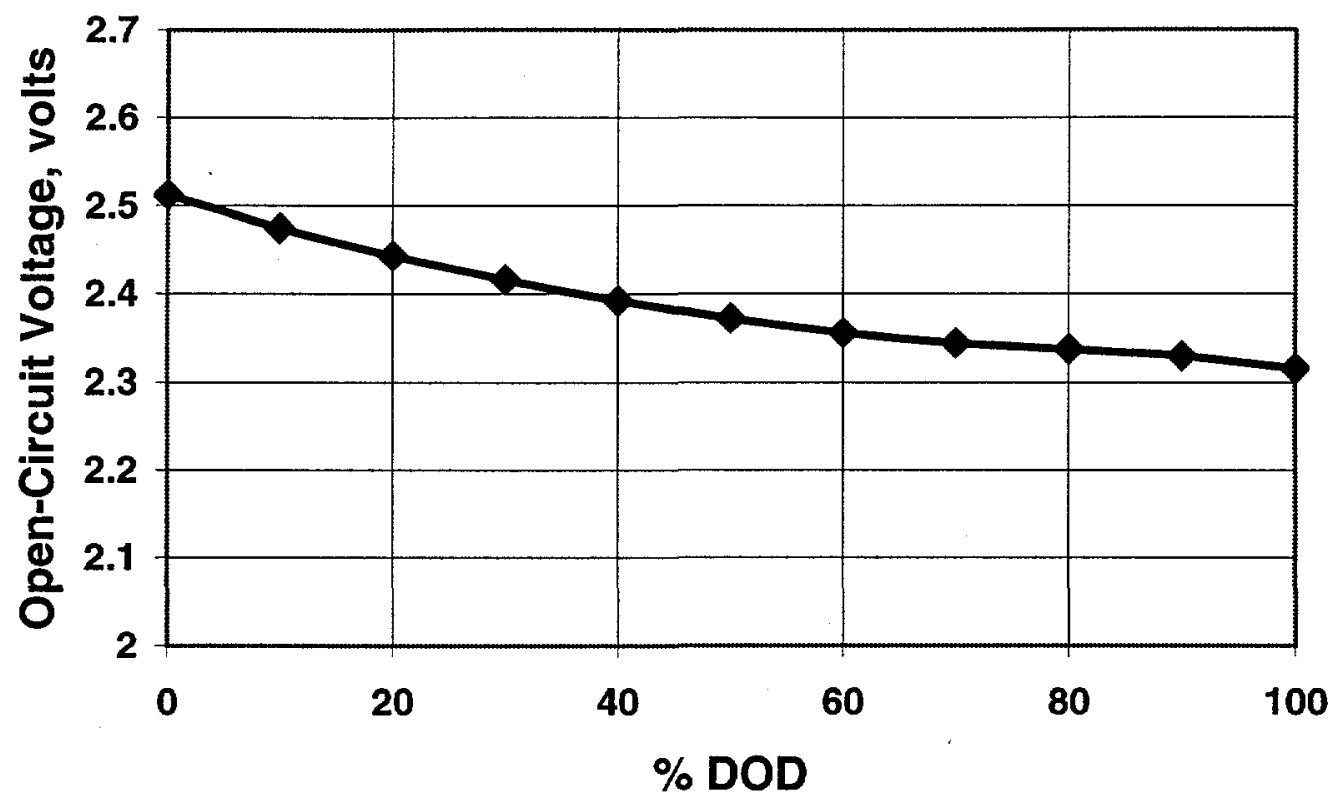

Fig. 4. Open-circuit voltage profile for a $\mathrm{Li}_{4} \mathrm{Ti}_{5} \mathrm{O}_{12} / \mathrm{LiCoO}$ cell as a function of depth of discharge (DOD) obtained after 47,500 cycles of the PNGV 100-Wh Test Profile. 


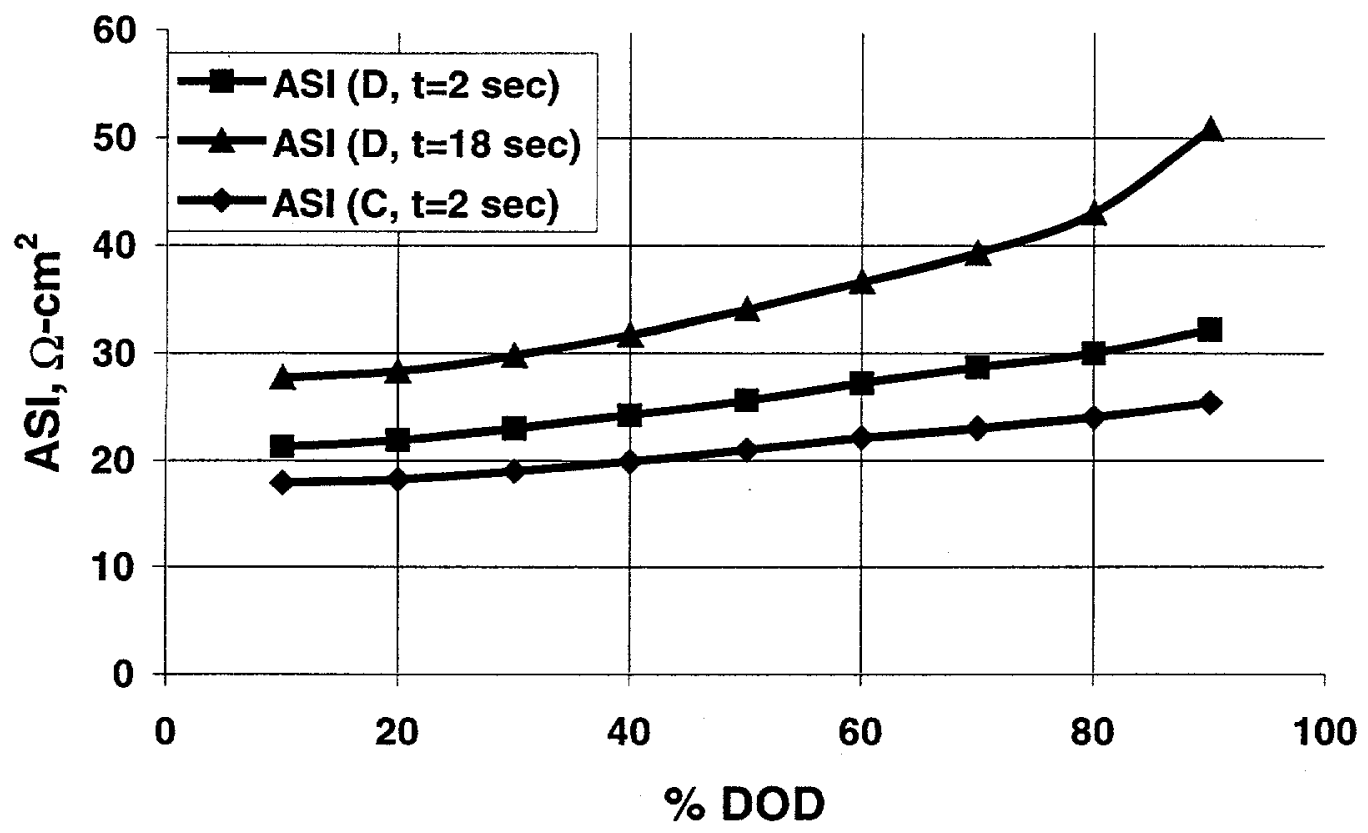

Fig. 5. Pulse-power area specific impedance (ASI) for a $\mathrm{Li}_{4} \mathrm{Ti}_{5} \mathrm{O}_{12} / \mathrm{LiCoO}$ cell obtained after 47,500 cycles of the PNGV 100-Wh Test Profile. 


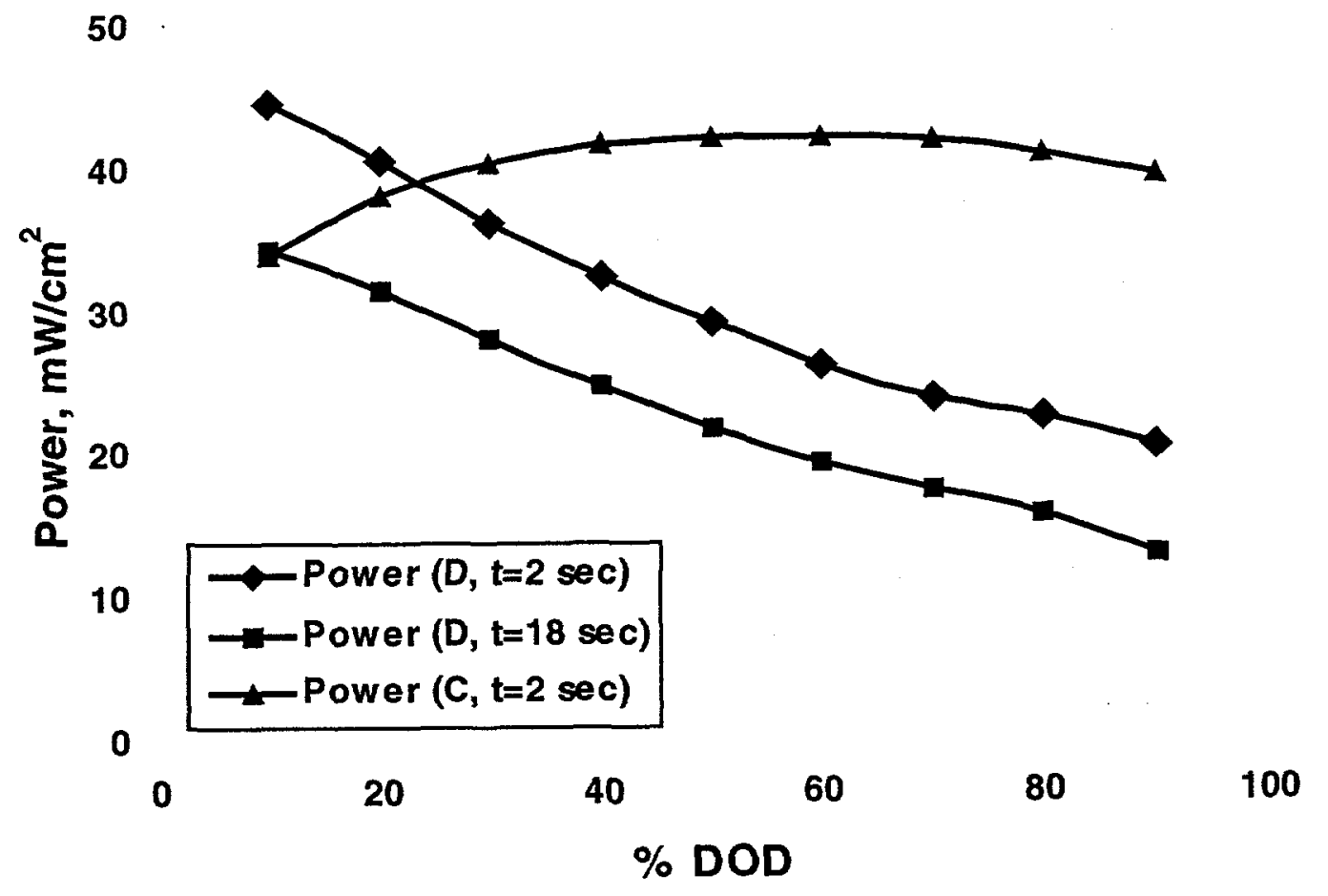

Fig. 6. Pulse-power capability ("Sweet Spot") plot for a $\mathrm{Li}_{4} \mathrm{Ti}_{5} \mathrm{O}_{12} / \mathrm{LiCoO}_{2}$ cell obtained after 47,500 cycles of the PNGV 100-Wh Test Profile. 